Article

\title{
Jewish Diaspora and the Stakes of Nationalism: Margarete Susman's Theodicy
}

\author{
Yael Almog \\ Department of Evangelical Theology, Goethe University, 60323 Frankfurt, Germany; yaelalmog6@gmail.com \\ Received: 31 December 2018; Accepted: 11 February 2019; Published: 12 February 2019 \\ check for \\ updates
}

\begin{abstract}
This article unpacks Margarete Susman's political and theological arguments at the core of her reading of the Book of Job. As I show through a reading of her oeuvre, Susman rejects political projects that she takes to be based on eschatology such as political Zionism. However, Susman should not be viewed merely as a critic of Zionism. I argue that an analysis tuned to the historical circumstances of her writing should recognize her stance on the nation-building project in Palestine as ambivalent rather than antagonistic. Susman's conception of the Jewish spirit as rooted in self-sacrifice allows her to appreciate the national aspirations at the core of the Zionist project while rejecting Zionism's exclusion of other Jewish national projects. I contend that Susman's understanding of Jewish messianism as immanent rather than teleological informs her ambivalence toward Zionism as well as her original vision of Jewish political action. I argue in closing that Susman's theodicy offers a novel vision for Jewish ethics that is not limited to the historical moment of its formulation. Susman's theodicy also resonates within contemporary debates on Jewish diaspora in providing a non-centralized vision of Jewish national projects.
\end{abstract}

Keywords: theodicy; Zionism; diaspora; modern Jewish history; Margarete Susman; German-Jewish history

\section{Introduction}

The philosopher Margarete Susman has not drawn the scholarly attention granted to other Jewish thinkers who reconsidered theology in view of the fatal violence against European Jews in the twentieth century. Not only did Susman provide penetrating tenets on postwar theology, but she also influenced the scholarship of such thinkers as Martin Buber and Gershom Scholem who took part in polemics on the role of theology for Jewish communities after the holocaust. Despite these contributions, her work is overlooked in such accounts as Zachary Braiterman's (God) After Auschwitz: Tradition and Change in Post-Holocaust Jewish Thought, which dedicates a separate, comprehensive chapter to Jewish theodicy (Braiterman 1998). Collected volumes dedicated to Jewish intellectuals' confrontation with the holocaust also ignore her contributions. Translations of her works into English (and into other languages) are scarce.

One explanation for the exclusion of Susman from the canon of Jewish philosophy of religion might lie in the eclectic style of her writing. Before her move to Switzerland in 1933, Susman was renowned in Germany as a sharp critic of cultural trends. After the war, she began to write theological articles that frequently commented on Jewish history by engaging Christian tropes such as redemption, blissful suffering, and guilt. Published in 1946, her book On the Book of Job and the Fate of the Jewish People (Das Buch Hiob und das Schicksal des jüdischen Volkes) is arguably the first extensive discussion of theodicy in post-Holocaust Jewish thought. Susman describes theodicy as intrinsic to Jewish existence and presents major aspects of Jewish suffering as emblematic of the modern human condition that she characterizes by discussing Kafka's prose. 
I contend that Susman's relative marginality in the philosophical canon can be attributed to her complex position on Jewish diaspora, which refrains from a binary opposition of nationalism and exile. Susman addresses exile as a metaphysical stance inherent to Judaism that reverberates in Jewish life in the diaspora and in the ghetto (Susman 1929, p. 378). At the same time, she refrained from rejecting Jewish nationalism, a stance echoed by prominent diasporist thinkers in her intellectual surroundings as well as those working in the present day.

In his examination of both rabbinic and Zionist texts on exile, Arnold M. Eisen revisits Jewish thinkers who have scrutinized the meaning of true homecoming as a spiritual venture that entails the restoration of a communal center. Polemics on Zionism often debate on the exact meaning of this act of spiritual reinstitution (Eisen 1986, pp. xii-xiii). As Eisen writes, "the concept galut has always had both a political dimension-the perils of statelessness, the disabilities of the alien-and a metaphysical dimension: a function of our brief sojourn as human beings on God's earth" (Ibid., p. xviii). In her comments on Job, Susman engages both aspects of Jewish exile and conceptualizes the relationship between them. In her mind, Job configures the misery of a people that is primarily defined by its homelessness (Heimatlosigkeit). Jewish suffering is informed in her eyes by the enduring lack of a homeland. Due to their suffering, Jews are granted a special symbolic status in modernity, an epoch in which disorientation and spiritual loss became an overall human experience. Other people see Jews as embodying existential suffering.

The immigration of Jews to Germany in recent decades, particularly from the former Soviet Union, appears to make Susman's theodicy ever more pertinent given her focus on German-Jewish relations as an apex of the socio-psychological dynamics at the core of Jewish exile. Her work could be read as aligning with writings by Jewish intellectuals who portray Jewish values as grounded in a diasporic existence. Abraham Rubin has recently retrieved the conceptual roots of Susman's theodicy as antagonistic to Zionism (Rubin 2016, 2017). In this venture, he argues that Susman's conception of the Jewish spirit opts to offer an alternative to the view of the Jewish state as the spiritual center of world Jews. Susman thus opposed the reiteration of this agenda in Buber's mystical vision that advertised the connection of Jews to the Land (Rubin 2016). The consideration of Susman as a diasporist thinker-who ostensibly opposed Zionism with the claim of adhering to the exilic Jewish spirit-accommodates the proliferating interest in invoking diasporic existence as inherent to Jewish history and in drawing ethical implications from this history (Butler 2012).

My own contextualization of Susman's theodicy will not subscribe to her reading as an opponent of Zionism. Revisiting Susman's comments on Job, I will reconstruct the argumentation that led Susman to an ambivalent position toward political Zionism-the efforts to establish a home for the Jewish people in Palestine in the form of a sovereign Jewish state. On the one hand, Susman reveals empathy to Zionism's enthusiastic national zeal and praise of self-sacrifice, but on the other hand, she sees exile as inherent to the Jewish people's continual existence. As I will show, Susman's ambivalence toward Zionism does not contrast with setting national projects as the pillars of Jewish collectives. In her polemics with Zionism, Susman does not target Zionism's nationalist nature, but rather its delegitimization of other Jewish national projects. I argue that Susman's relevance to discussions of Jewish diaspora derives exactly from her complex approach to Zionism. In this venture, her references to Job can be seen to constitute a political theology that does not pertain to a sovereign nation state, but rather to multiple national projects.

\section{Job, Kafka, and the Longing for a Nation}

In his introduction to a collection of Jewish theological responses to the holocaust, Gershon Greenberg points out "the delay in integrating Holocaust era religious thought into the history of Jewish thought" (Greenberg 2007, p. 11). The case of Susman's theodicy is exceptional since her writings that are informed by the holocaust largely continue her descriptions of the Jewish spirit composed in earlier years. Susman's early works reflect on Jewish suffering and salvation-tropes that 
proliferated in Jewish theology after the Holocaust (for a collection of representative post-holocaust commentaries on the Old Testament, see Linafelt 2000).

Susman developed the principles of her theodicy, particularly those that build on her interpretation of modernist literature, already in her 1929 essay "The Job Problem in Kafka" (Das Hiob Problem bei Kafka). The beginning of the essay compares the prophet Jeremiah's conflict (Hader) with God to Job's. Those two biblical books use similar semantics to unfold narratives of individualistic struggle that are at their core. As Michael Fishbane notes, those books make an equivalent repetition of images from Genesis that echo the creation stories while linking them to destruction (Fishbane 1971).

Notwithstanding the semantic similarities between those narratives, whereas Jeremiah knows the reason for his suffering, Job lacks such assurance. For Jeremiah, Susman explains, the conflict with God was framed by his ultimate embrace of his national mission as a prophet of Israel, whereas Job was alone with God while facing misery and confusion. Susman lists Job's friends, his people, and the entirety of humankind as oblivious to the inner process that Job was going through. She concludes that, with Job, the experience of a collective existence in the face of misery has collapsed. According to her reading of the biblical book, Job is occupied with inner deliberations that cannot be transmitted to the outside world.

In Susman's view, Job's isolation persists even as he holds a dialogue with God. The divine response to Job does not bring about reconciliation with God. Rather, Susman argues, God poses Job a counter-question (Gegenfrage) that leaves Job perplexed and deepens his existential solitude (Susman [1929] 1992, p. 186). Like Job, the Jewish people understands its suffering as a punishment from God. And like Job, this people tries incessantly to understand the reason for its suffering. As will be elaborated henceforth, according to Susman, whereas all people were doomed to suffering, Israel was chosen by God to suffer. She rewrites the idealized image of the Jewish people as the selected few-an image which served as a model for Christian nationalism—while preserving the exemplary status of these people. Susman concludes: "There is no great feat of Judaism in exile which is not a theodicy in its core" (Ibid. All translations are my own if not mentioned otherwise). The fate of the Jew in the West becomes synonymous with Job's image in the eyes of his surroundings. According to Susman, the Jewish people exhibit their incessant attempts to decipher the grounds for their suffering. In the process, suffering becomes this group's emblematic trait.

Susman sees modernity as an apex of this dynamic since this epoch has seen the transformation of metaphysical confusion into a universal human experience. She contends that modernist prose reflects this transformation. She considers Kafka's works an exemplary representation of this human experience because it transmits to his readers a radical form of human solitude. The metaphysical dilemmas manifested in Kafka's work parallel those of Job: like him, Kafka's narrator is occupied with the reasons for human suffering. Kafka's world generates solitude: a dense depiction of reality through a set of individual reflections that express the individual's agony that cannot be shared with others. Kafka's prose constitutes a labyrinth of metaphysical dilemmas that cannot be solved. Kafka's literary works thus mirror Job's fate. In Susman's mind, both voice the painful fate of Judaism in exile (Ibid., p. 188).

In both her "On the Problem of Job in Kafka" and The Book of Job and the Fate of the Jewish People, Susman defines the grounds for Jewish suffering as dual: Jews lack a physical homeland; and their homelessness intensifies their metaphysical disorientation. Christians still enjoy the world that God has given them, because it is embodied in their homeland. Their connection to the homeland therefore eases the disappointment of a break with God (a universal modern experience). Entrenched in exilic existence, Jews cannot rejoice at their surroundings because they lack an immediate connection to their place of residence. World War I was an apex for individuals' identification with their homelands-a connection sacralized through corporal self-sacrifice, injury, and death. Susman's notion of theodicy relies on her view that the unmediated sentiment of national belonging is part and parcel of the Christian world experience. Because Jews lack a similar connection to the fatherland, their relationship to God is crucial for their orientation in the world: "The Jew rises and falls with his God. For the 
Christian the entire world still remains; since in it the Godly has previously revealed itself to him, and it [the world] beams from that for eternity. When the Jew has lost his God, he has lost everything" (Ibid., p. 189). In her mind, the loss of God manifested in the unsatisfying dialogue with the divine is the defining motif of the Book of Job—a narrative that Susman takes to model Jewish history.

\section{Correspondence with Anti-Jewish Accusations}

The view of Jews as aliens who cannot fully assimilate into their national surroundings is an old one. This characterization gave rise to seminal depictions of Jews in modernity as much as it set the tone for major depictions of national belonging. Johann Gottfried Herder, a prominent forerunner of modern nationalism, characterized Jews as lacking a defined territory. In such works as Letters for the Advancement of Humanity and Ideas on the Development of Humankind, he contends that a national spirit is unique to a nation that populates a defined territory. The national spirit forms the literary canon composed in the vernacular that is transmitted throughout a nation's life. Yet what happens when a group features ethnic and cultural homogeneity, but does not populate a defined territory? In Herder's view, Jews have long held such a status and are thus comparable to other nomadic peoples: "The preservation of Jews clarifies itself just as naturally as the preservation of Brahmans, Parsis, and Gypsies" (Herder 1989, p. 491). To understand Herder's position, one should note that he took gypsies to have a destructive impact on European populations-they do not assimilate into the nations where they reside and can hardly be mobilized to support nations' well-being (Ibid., p. 703). Jews bear a similar danger. According to Herder, Jews have lost the national traits manifested in the glorious times of ancient Israel. Their use of language shows their destructive hybrid existence as guests among the nations. Post-antiquity Jews corrupted biblical Hebrew, which used to be a supreme national language, and at the same time they damaged the vernaculars of the countries where they resided (Herder 1993, p. 678).

As Abraham Rubin has pointed out, Susman appropriates the logic of anti-Jewish discourse by focusing on accusations that associate Jews with anti-traditionalist dangers (Rubin 2016, p. 7). Susman could have concentrated on negative descriptions of Jews as hindering social progress. Instead she addresses-and transgresses-accusations that Jews corrupt local national cultures with a disruptive modern influence. According to this view, Jews' homelessness is destructive to the well-rooted national cultures. Susman contends that Jewish disorientation in the world voices the modern individual's experiences. This characterization of modernity as uniquely Jewish accommodates the tenet that hegemonic literary narratives of exile, such as James Joyce's, build on the figure of the wandering Jew while introducing it to the general corpus of travel literature (Ezrahi 2000, p. 8).

In his provocative work The Jewish Century (Slezkine 2004), Yuri Slezkine argues that the twentieth century brought to a head the tensions embodied in Judaism as a symbol of national belonging. According to Slezkine, Jews functioned for centuries as external social agents who supplied the needs of local European societies. Jews practiced such professions as law, medicine, and commerce-occupations that distinguished them from individuals rooted in society. Prior to modern times, Jews were one group among other permanent strangers living among European societies (Slezkine 2004, p. 4). While the agrarian society "sacralized space," nomads were "wedded to time, not land" (Ibid.). According to Slezkine, Jews personified the hazards of modernity primarily through their image as homeless. Jews became victims of the social structures that rendered them aliens to nation-states rather than equal residents in them. The economic success of Jews heralded their subsequent persecution as outsiders to European nations. According to Slezkine, the lethal history of Jews in Europe throughout the twentieth century is steeped in social transformations that generated anxieties regarding modernity. These transformations made the position of Jews in European societies ever more precarious. As members of European societies, Jews appeared especially mobile. Along these lines, Slezkine points out the large percentage of Jews attending European institutes of higher education. Jews appeared to master skills that enable one to thrive in modernity: their geographical mobility echoed their ostensible social, economic, and professional mobility. 
The period prioritized social and economic mobility over traditional occupations bound to the land, such as agriculture; subsequently, Jews appeared to be skillfully modern in a society that both encouraged their traits and was alarmed by their potential hazards. Susman's theodicy resembles Slezkine's description of the twentieth century as "the Jewish Century." She sees images of the Jewish spirit that are long-lasting, particularly homelessness, as epitomizing the anxiety of the metaphysical disorientation of the modern individual. Susman takes the lethal persecution of European Jews not as a break with the history of Jewish-Christian relations but as its immanent component. As we shall see, she conceives Jews' striving for a homeland as entrenched in this history. In her mind, the Jewish incessant hope for national belonging is the driving force of their political actions including death on the battlefield.

\section{Susman's Messianism}

Susman's conception of suffering as inherent to Jewish history is bound with her understanding of messianic hope as steeped in self-sacrifice. Susman unfolds a political theology that centers on theodicy. This worldview accommodates Jewish national endeavors that are immanent rather than teleological; regional rather than centralized; and sober rather than eschatological.

As early as 1915, in an essay on Spinoza, (Susman 1915) contended that the promise of the Messiah's arrival in Jewish thought builds on readiness for self-sacrifice. The Jewish believer is not merely prepared to follow divine laws; he or she is ready to make a sacrifice that goes beyond the law's normative dimension. Self-sacrifice manifests "love" - the affective attachment to God that fuels the anticipation of the Messiah. Susman writes,

The thought of the Messiah lives deeply in the root of Judaism, and through the entire Old Testament, so strict and severe, love shines like a spark that both desires and is compelled to seize the world and that will only burst into flame when it has been fully grasped. This is the love that still lives here exclusively in the simple mantle of the fulfillment of the law and yet, as in the binding of Isaac, already develops out of itself a burning readiness for sacrifice [that goes] beyond obedience-as well as the love, expressed in Joseph's simple word to his brothers, "Do not fear, for I am under God" (translation in Hillmann 2013, p. 68).

Susanne Hillmann cogently argues that Susman develops a vision of "slow messianism": a messianic perception of history that builds on hope (Hillmann 2013). Hillman demonstrates that this specific stress on affect makes Susman react to Zionism with ambivalence. Zionism is a climactic moment of Jewish history: it manifests a national perception that centers on self-sacrifice. At the same time, it opts to end Jews' exile, which is, in Susman's opinion, their inherent trait.

Susman admired many things about Zionism. An avid supporter of socialism, which she saw as an ideology that should guide all social coexistence, she appreciated the kibbutzim: cooperative units that made for a large number of the first settlements in Israel. In 1919, (Susman [1919] 1965) confessed to Buber that if she were still young, she would move to Palestine and invest herself in "a life not yet robbed of sanctification" (Buber 1991, p. 244). This enthusiastic description of Zionism resonates with Buber's own perception of nationalism. When World War I broke, Buber called the Jewish youth to serve in the armies of their respective European homelands. Because he was already a well-known and influential figure among assimilated Jews, this appeal encouraged many to join the war. Buber's call for Jewish youth to join the war provoked an uproar among those who opposed the notion that Jews should be loyal to European nations. Buber's message thus outraged the young Gershom Scholem who was influenced by his brother Werner, an anti-war activist (Zadoff 2018, pp. 112-113). Scholem's critique of Buber's early position on patriotism persisted in their diverging visions of Zionism and Jewish life in Israel. Contrasting the appeal for physical self-sacrifice featured in both Buber and Susman's oeuvres, Scholem contended that the nation-building project should revolve around the conceptualization of Israel as a spiritual center. This vision exchanges the emphasis on individuals' attachment to the soil with the portrayal of Jews as taking part in a long-lasting intellectual, liturgical, 
and spiritual tradition. In Susman's opinion, the Yishuv provided a virtuous form of communal Jewish living that manifests Jews' incessant search for national belonging.

Whereas Susman admired the self-sacrifice embodied in the Zionists' endeavor, her theological vision made her reject the ultimate vision of the main strands of political Zionism: the ending of exilic Jewish life through the establishment of a nation state. Zionism undertook Zion as a concrete location for the modern Jewish state. (Susman [1919] 1965) unpacks her opinion on Zionism in a lecture from 1919 that focused on the sacrifice of the lives of Jewish soldiers during World War I. There, Susman compares the European Jewish soldiers to Jews who suffer in the other Zion, namely in the Yishuv. Susman locates Jewish self-sacrifice driven by national sentiment in both Europe and Palestine. This comparison is soon exchanged with a critique of the Zionist separatist self-perception:

Can and should the Jews become a people like other peoples? Is this the destiny for which they have preserved themselves for 2000 years? Does the creation of a legally secured homeland in Palestine really constitute the solution of all their problems, the fulfillment of all their duties and assigned tasks, or at least the sole feasible and fruitful path thereto?" (translation in (Hillmann 2013, p. 47)).

Contrary to this view, Susman claims that the Jews had been called upon to "live towards, suffer towards, and love towards the coming of the Messiah" by "making space for a better, purer life" (Ibid., p. 48). This is a vision that gives the Jewish people a symbolic role that is different from other nations; this people was chosen to suffer. This fate manifests itself first and foremost in the exilic life of Jews.

In her The Book of Job and the Fate of the Jewish People, Susman reiterates several of the theological principles developed in her previous work. What makes the publication of this work dramatic despite this ostensible repetition, is the fact that it was published after the holocaust, in 1946. Escaping to Switzerland in 1933, Susman was fully aware of the horrors of the holocaust. As a refugee, she lost both her cultural impact and economic means and became dependent on the benevolence of her friends in her new place of residence. She subsequently described her own life as overburdened by historical and personal catastrophes (Susman 1964, p. 23).

The persecution of Jews under National Socialism drew attention to Susman's description of suffering as the inherent characteristic of Jews. The historical circumstances provoked vocal critique of her book's depiction of Jewish theodicy which was taken to idealize and even justify the Jewish suffering in the holocaust. The Book of Job and the Fate of the Jewish people explains a hatred of Jews that persists, according to Susman, at all times. Susman insists that being Jewish is a decision that one makes notwithstanding one's belonging to the Jewish community by birth. Susman contends at the beginning of her essay that one's decision to become Jewish draws its dramatic nature from the Jewish experience of dual exile. On the one hand, Jewish existence is detached from a nation state; on the other hand, it dwells in a mode of existential crisis.

This dual source of misery makes Job emblematic of the Jewish fate. Susman takes Job's existential reflections and misery to center on the circularity of punishment and guilt: "In that he seeks God's justice helplessly, without finding it, he is forced to look for his own guilt. But exactly that which troubles him most deeply, that which for him touches most deeply God's justice, he cannot find" (Susman [1946] 1968, p. 58).

Susman repeats her claim that other nations witness the Jews' suffering and identify them with that condition. Germans and Jews inhabit a conflicted space in which Jews reflect the human struggle to grasp the ground for suffering. Whereas non-Jews do not suffer from the physical disorientation and homelessness that characterize Jewish life, they can identify well with the second, metaphysical, facet of Jewish suffering. The experience of an alarming breach between man and God colors the human condition in modernity, encapsulating the secularization of the West. Therefore, the modern age grants Jews a symbolic function in representing the all too human experience of the modern collapse of spiritual assurance.

Due to their lack of a territorial center, Jews are in special need of assuring a connection to God. Because the Jews are unable to secure divine guidance, they represent the metaphysical disorientation 
common to all nations in the age of secularism. The sociopolitical implications of Jewish theodicy culminate in modernity, an age where the status of Jews as the chosen people converges with their unique suffering. In this epoch, a certain facet of Jewish theology takes over, coloring and shaping the confessional difference between Jews and non-Jews.

Susman's account of theodicy is powerful because it draws on secularism. Rather than declaring secularism antagonistic to theology or ignoring it altogether, Susman declares this cultural transformation as intertwined with Jews' unique spiritual role in the world. Susman's description of the breach between the individual and God in modernity guides her view that humans are deprived of divine revelation in the world-a description of mysticism that contrasts Buber's description of the Chassidim as embodying such direct spiritual experience (Delf 1993, pp. 254-55). In contrast to this view, Susman adheres to a notion of messianic hope as hopeless—a paradox that she sees as integral to Jewish history (Ibid., p. 255).

The establishment of a Jewish state is at odds with this theological worldview. Susman revisits political Zionism in her introduction to the second edition of The Book of Job and the Fate of the Jewish People published in 1948. The prologue reflects Susman's view of the efforts to establish the State of Israel as an exceptional historical event. On the one hand, she contends that the struggle for a Jewish state is just: that the remarkable endeavor to transgress the long-lasting history of Jews parallels the intensity of Jewish suffering in the twentieth century. The Zionist project stresses the gravity of the incomparable horrors of the holocaust. But while it reaffirms Jewish theodicy, the nation-building project also dismantles the logic behind it. A Jewish nation opts to make Jews equal actors in the system of world nations. It wishes to bind the Jewish spirit to a certain territory. This political vision ultimately cancels out the status of Jews as the chosen people.

\section{Susman's Theodicy and Current Debates on Jewish Exile}

A major outstanding aspect of Susman's conception of Jewish theodicy is that it did not undergo major changes in view of the holocaust. Thus, Susman maintained her depiction of Job's suffering as explanatory of Christian-Jewish relations instead of turning to new interpretations of the book in the framework of Jewish theology. Because she grounds the Jewish fate in Christian-Jewish cohabitation, Susman rejects the notion that a Jewish sovereign state would dissolve the symbolic status of Jews among the nations as inherently homeless. Susman's position can be described as diasporic: she rejects Zionism's attempt to end Jewish homelessness. Yet at the same time, Susman develops an understanding of politics through the prism of messianism - a theory that relied on the correspondence of all forms of politics with human epistemology (see Klapheck 2011, especially p. 24).

In closing, I would like to suggest that Susman's grounding of real politics in Jewish theodicy may enrich contemporary conceptions of Jewish diaspora and exile. Recent political critiques of Zionism have found their departure in diasporic Jewish identity-a position that cancels out the belief in a sovereign Jewish state as the ultimate goal of Jewish politics. Judith Butler's Parting Ways: Jewishness and the Critique of Zionism stood at the center of recent polemics on the (un)conditional support that the world Jewish community may or may not offer the State of Israel in light of Israel's political actions and particularly the military occupation of Palestinian territories. A supporter of the boycott on Israel (the BDS movement), Butler proposes that ostensible diasporic values-values she associates with the long-lasting Jewish history and thought-may benefit the State of Israel, if they are ingrained in its political environment:

[N]ot only is there substantial evidence that dispersion is the mode in which Jews have in fact survived, but the idea that dispersion is a threat to Jews that must be overcome often relies on the notion that "dispersion" is a form of exile from the homeland (a condition of galut that can only be reversed through "returning" to the homeland). If dispersion is thought not only as a geographical situation but also as an ethical modality, then dispersion is precisely the principle that must be "brought home" to Israel/Palestine in order to ground a polity where no one religion or nationality may claim sovereignty over another, where, in fact, sovereignty itself will be dispersed. (Butler 2012, p. 6). 
Formulating this ethical vision, Butler references Levinas's vision of empathy: a vision that addresses the boundaries between the "you" and the "I" (Ibid., p. 10).

Julie Cooper has argued that Butler's attempt to base ethics on Jews' identity as nationless fails to propose a cogent political vision because it does not respond to the needs that Zionism sought to address. Cooper thus takes the concept of dispossession to be an essential aspect of Butler's understanding of Jewish identity. Butler establishes this notion by discussing the imperative to love the foreigner as oneself. In Butler's view, this is an ethical position steeped in one's ability to transgress the boundaries of the "I". This "self-departure" dictates an empathetic stance towards non-Jews (Butler 2012, p. 5). It is from within this position that Butler criticizes Zionists who disregard the impact of the nation-building project on local Arabs in Palestine. At the same time, Butler is also critical of proponents of cultural Zionism who attempt to make the Jewish state a spiritual center for Jews based on an essentialist view of Jewishness (Cooper 2015, p. 93).

Cooper takes Butler's arguments to be philosophically coherent: she understands the notion of self-departure as successful in generating ethical values. At the same time, she believes that Butler fails to address pertinent concerns to which Zionism claims to respond:

To derive generalizable ethical principles (applicable to Jews) is not ... to examine how this dispersed people can exercise political agency and confront political challenges. A compelling critique of Zionism, I would argue, must offer historically informed rejoinders to Zionism's diagnosis of the Jews' vulnerability as a stateless people. Such rejoinders may culminate in the endorsement of polities that Butler would judge ethical—but they cannot rely solely or primarily on general ethical principles (Ibid., p. 94).

Based on this analysis of Butler, Cooper contends that Butler's critique of Zionism does not propose a cogent political vision for what she terms Jewish polities. Butler does not respond to the historical backdrop behind the Zionist national project: the long-lasting existence of Jews as homeless that made them vulnerable to anti-Semitic violence. According to Cooper, more sustainable diasporic critiques of Zionism should envision an alternative of political collectives to the Zionist model of a sovereign Jewish state. Such models for Jewish self-rule may go beyond the nation state altogether (Ibid., p. 108).

Susman's theodicy may align with the attempt to rethink Jewish political agency as decentralized. Susman's notion of theodicy envisions Jewish identity as grounded in a diasporic position while at the same time accommodating political action. My analysis has stressed two principles of her thinking that evince her accreditation of Jewish political agency: her view of self-sacrifice as an ultimate feature of the Jewish spirit, and the interrelated conception of Jews as a collective. In Susman's mind, these two principles can converge through national projects such as Jewish patriotism and army service. Susman's comparable sympathy to the Zionist efforts to establish a Jewish state reveals her appreciation of the Zionist adherence to self-sacrifice. With this position in mind, I recognize Susman as a thinker who provides insights into visions of Jewish nationalism that have been marginalized and forgotten, precisely because of their non-binary stance on Zionism. Susman should interest us today not because she opposes Zionism through a rejection of Jewish nationalism altogether, but because she conceptualizes alternative Jewish nationalist projects that are not separatist nor exclusive.

Susman's relevance today goes beyond debates on Jewish diaspora as compliant with nationalism. During Susman's lifetime, the interest in Zionism centered on this movement's status as an eschatological revolution which sought to amend the long-lasting status of a people. Eschatology has been the topic of major attempts to reflect both on the course of twentieth-century history and on historiography. As a historiographical trope, eschatology provoked Karl Löwith and Hans Blumenberg's famous debate regarding historians' ostensible use of religious vocabulary in their description of progress. The discourse on historiography has given less attention to the function of other theological tropes in historical accounts. Susman's slow messianism may point to just that. Her theodicy, which depicts messianism that is not eschatological, hints at the manifold impacts of theology on historical consciousness. 
Funding: The author wishes to thank the Federal Ministry of Education and Research (BMBF) of Germany for funding received during the writing of this article.

Conflicts of Interest: The author declares no conflict of interest.

\section{References}

Braiterman, Zachary. 1998. (God) After Auschwitz: Tradition and Change in Post-Holocaust Jewish Thought. Princeton: Princeton University Press.

Buber, Martin. 1991. The Letters of Martin Buber: A Life of Dialogue. Edited by Nahum Glatzer and Paul Mendes-Flohr. Translated by Richard, Clara Winston, and Harry Zohn. New York: Schocken Books.

Butler, Judith. 2012. Parting Ways: Jewishness and the Critique of Zionism. New York: Columbia University Press.

Cooper, Julie. 2015. A Diasporic Critique of Diasporism: The Question of Jewish Political Agency. Political Theory 43: 80-110. [CrossRef]

Delf, Hanna. 1993. In diesem Meer von Zeiten, meine Zeit!: Eine Skizze zu Leben und Denken der Margarete Susman. In Von einer Welt in die andere: Jüdinnen im 19. und 20. Jahrhundert. Edited by Jutta Dick and Barbara Hahn. Vienna: Christian Branstätter, pp. 248-65.

Eisen, Arnold M. 1986. Galut: Modern Jewish Reflection on Homelessness and Homecoming. Bloomington and Indianapolis: Indiana University Press.

Ezrahi, Sidra DeKoven. 2000. Booking Passage: Exile and Homecoming in the Modern Jewish Imagination. Berkeley: The University of California Press.

Fishbane, Michael A. 1971. Jeremiah IV 23-26 and Job III 3-13: A Recovered Use of the Creation Pattern. Vetus Testamentum 21: 151-67.

Greenberg, Gershon. 2007. Introduction. In Wrestling with God: Jewish Theological Responses during and after the Holocaust. Edited by Steven T. Katz, Shlomo Biderman and Gershon Greenberg. Oxford: Oxford University Press.

Herder, Johann Gottfried. 1989. Johann Gottfried Herder: Ideen zur Philosophie der Geschichte der Menschheit. Edited by Martin Bollacher. Frankfurt a.M.: Deutscher Klassiker Verlag.

Herder, Johann Gottfried. 1993. Johann Gottfried Herder: Schriften zum Alten Testament. Edited by Rudolf Smend. Frankfurt a.M.: Deutscher Klassiker Verlag.

Hillmann, Susanne. 2013. "A Germ So Tiny": Margarete Susman's Messianism of Small Steps. Soundings: An Interdisciplinary Journal 96: 40-84.

Klapheck, Elisa. 2011. Margarete Susman und ihr Jüdischer Beitrag zur Politischen Philosophie. Ph.D. dissertation, The University of Flensburg, Flensburg, Germany.

Linafelt, Tod. 2000. Strange Fire: Reading the Bible after the Holocaust. New York: New York University Press.

Rubin, Abraham. 2016. Nihilism, Modernity and the "Jewish Spirit": Margarete Susman's Transvaluation of a Fin-de-Siècle Trope. Shofar: An Interdisciplinary Journal of Jewish Studies 34: 1-25.

Rubin, Abraham. 2017. Jewish Self-Affirmation out of the Sources of Christian Supersessionism: Margarete Susman's The Book of Job and the Fate of the Jewish People. Jewish Studies Quarterly 24: 168-93. [CrossRef] Slezkine, Yuri. 2004. The Jewish Century. Princeton: Princeton University Press.

Susman, Margarete. 1965. Die Revolution und die Juden. In Vom Geheimnis der Freiheit. Gesammelte Aufsätze 1914-1964. Edited by Manfred Schlösser. Darmstadt: Agora, pp. 122-43. First published 1919.

Susman, Margarete. 1992. Das Hiob Problem bei Kafka. In "Das Nah- und Fernsein des Fremden": Essays und Briefe. Frankfurt a.M: Suhrkamp, pp. 183-203. First published 1929.

Susman, Margarete. 1968. Das Buch Hiob und das Schicksal des jüdischen Volkes. Freiburg: Herder. First published 1946. Susman, Margarete. 1915. Spinoza und das jüdische Weltgefühl. In Vom Judentum. Ein Sammelbuch. Leipzig: Kurt Wolff Verlag, pp. 51-70.

Susman, Margarete. 1929. Die messianische Idee als Friedensidee. Der Morgen 5: 375-85.

Susman, Margarete. 1964. Ich Habe viele Leben Gelebt: Erinnerungen. Stuttgart: Deutsche Verlags-Anstalt. Zadoff, Mirjam. 2018. Werner Scholem: A German Life. Philadelphia: The University of Pennsylvania Press.

(C) 2019 by the author. Licensee MDPI, Basel, Switzerland. This article is an open access article distributed under the terms and conditions of the Creative Commons Attribution (CC BY) license (http:/ / creativecommons.org/licenses/by/4.0/). 